\title{
Efficient Removal of La(III) and Nd(III) from Aqueous Solutions Using Carbon Nanoparticles
}

\author{
Alaa M. Younis ${ }^{1}$, Artem V. Kolesnikov ${ }^{2}$, Andrei V. Desyatov ${ }^{3}$ \\ ${ }^{1}$ Aquatic Environment Department, Faculty of Fish Resources, Suez University, Suez, Egypt \\ ${ }^{2}$ Science Department, Mendeleyev University of Chemical Technology of Russia, Moscow, Russia \\ ${ }^{3}$ Department of Industrial Ecology, Mendeleyev University of Chemical Technology of Russia, \\ Moscow, Russia \\ Email: ala den@yahoo.com
}

Received 17 October 2014; revised 2 December 2014; accepted 16 December 2014

Copyright (C) 2014 by authors and Scientific Research Publishing Inc.

This work is licensed under the Creative Commons Attribution International License (CC BY). http://creativecommons.org/licenses/by/4.0/

(c) (i) Open Access

\begin{abstract}
Environmental pollution caused by release of toxic metals (rare earth elements, etc.) into aquatic environment as a result of industrial activity is one of the serious global issues, thus development of different efficient methods for removal of these metals from wastewaters seems to be important subject today. Carbon nanoparticles (CNPs) are well-known to have the superior adsorption efficiency toward heavy metals in aqueous solution. However, little research has been dedicated to exploit their use for the removal of rare earth elements (REEs) from contaminated water. Therefore, the environmental application of CNPs to remove Lanthanum (La III) and Neodymium (Nd III) from wastewater was performed. In this work, Adsorption experiments were carried out by batch mode adsorption to investigate the influence of different conditions that enhanced the adsorption of La(III) and Nd(III) by CNPs such as $\mathrm{pH}$ of solution, adsorbent dose, contact time, and initial concentration of investigated rare earth elements. The obtained results showed that the optimum adsorption for the removal both studied metals from contaminated water were $0.02 \mathrm{~g} / 25 \mathrm{ml}$ of CNPs at pH 7.0 after 40 min of adsorption. This work demonstrates that CNPs can be considered as potential adsorbents to target metal ions from wastewater.
\end{abstract}

\section{Keywords}

Carbon Nanoparticles, Aqueous Solutions, Rare Earth Elements, Adsorption

\section{Introduction}

One of the world's major environmental problems is the disposal of large volumes of wastewater containing

How to cite this paper: Younis, A.M., Kolesnikov, A.V. and Desyatov, A.V. (2014) Efficient Removal of La(III) and Nd(III) from Aqueous Solutions Using Carbon Nanoparticles. American Journal of Analytical Chemistry, 5, 1273-1284. 
heavy metals.

In recent years, the presence of heavy metal ions in aquatic environment systems had become much more serious and attracted attention with a rapid development of industries and listed as high priority contaminants by the 2007 CERCLA Priority List of Hazardous Substances compiled by the US Environmental Protection Agency (EPA) [ATSDR, 2007], due to their adverse effects on public health and their toxicities in relatively low concentrations in ecological systems [1]-[4].

As heavy metals do not degrade biologically like organic pollutants and can accumulate in living tissues, their increase in ecosystem effluents is a public health problem because of their tendency towards bioaccumulation in higher trophic concentrations of the food chain through waste discharge into bodies of water. Therefore, more stringent requirements for the removal of these toxic metals from wastewaters before releasing into the environment are required [5] [6]. Consequently, their presence in wastewater requires treatment and strict environmental regulations on the discharge of metal ions as well as rising demand for clean water with extremely low level of heavy metal ions make it greatly important to develop different efficient methods of removing metal ions from wastewaters before releasing into the environment [7]. Therefore, heavy metal ions removal from water has become an important subject today.

Extensive industrialization and improper disposal are attributed to be a prime factor responsible for the release of toxic metals into the ecosystems. The main sources of these metals are metallurgical, chemical manufacturing , mining, tannery, fossil fuel, battery manufacturing industries, the modern chemical industry is based largely on catalysts, production of plastics, such as polyvinyl chloride, involves the use of metal compounds, particularly as heat stabilizers etc. [8].

A variety of water remediation technologies have been used to remove heavy metals from aqueous solution include chemical precipitation, ion exchange, membrane filtration [9], coagulation and flotation [10], solvent extraction [11], and adsorption [12].

Among the different technologies described above, adsorption technique is considered simple operation, economy, fastness, efficiency, and a lack of harmful by products; moreover, both the adsorbent and the pollutants can be regenerated, these advantages making it a promising alternative to costly removal methods for the separation and removal of heavy metals from polluted water [13]-[17].

The common adsorbents which have been studied for adsorption of metal ions include fly ash [18] [19], activated carbon [20] [21], kaolinite, crab shell [22], manganese oxides [23], zeolite [24], biomaterials [25] [26] have been reported to be capable of adsorbing heavy metal ions from aqueous solutions.

With the emergence of nano science and technology in the recent years, a great deal of attentions has focused on to the unique properties of nonomaterials [27], such as high surface area and adsorption capacity, unsaturated surfaces, simple operation, and simple production [28] [29].

Much research on carbon-based nanoparticle in the environment has been devoted to elucidate the physical, chemical, and biological mechanisms that affect their stability, mobility and toxicity [30]. As a new member of carbon family, carbon nanomaterials (CNMs) may exist in numerous forms, such as, multi-walled carbon nanotubes (MWCNTs), carbon beads, single-walled carbon nanotubes (SWCNTs), carbon fibres and nanoporous carbon [27].

Activated carbon is the common adsorbents which have been studied for adsorption of heavy metal ions but few data are available about CNMs which offer a better surface area for adsorption, higher thermal and chemical stabilities, surface functional groups and also the recent progress in their large-scale production make them attractive for prospective environmental applications because their adsorption characteristics are better in comparison to conventional adsorptive materials [31].

Carbon nanomaterials exhibit great potential for the adsorption removal of different kinds of pollutants such as metallic ions [32] [33], synthesized dye [34], dichlorodiphenyltrichloroethane and its metabolites in water samples [35], organophosphorous pesticides in wastewater sludge [36], chlorophenol [37], polyhalogenated organic pollutants and, polyaromatic hydrocarbons in environmental water samples [38] [39].

Rare earth elements (REEs) are extensively recognized by geochemists as useful geotracers for many geological processes and their application fields are extensive, as a consequence of their peculiar spectroscopic and magnetic properties [40] [41].

Recently, REEs have been widely used in the several disciplines: coordination chemistry, organometallic compounds, luminescent compounds, catalysis, solid state chemistry, metallurgical machinery such as laser, the petroleum chemical industry, glass ceramics, electronic information storages, textile and light industry, pharma- 
cy and environmental chemistry [42]-[44]. REEs are also used in agriculture to improve the yield and quality of crops as well as the production of animal in many countries [45] [46].

Lanthanum and Neodymium have been widely used in Russia in electronics components, artistic glasses, optic filters, steel modifiers, and hydrogen stockage. Because of their applications in various fields, the content of these metals have increased in the environment.

REE-based applications in expansive districts and various fields over a long period of time have increased the content of REEs in the environment [47] [48]. Therefore, the increase in REEs level in the environment caused by anthropogenic activities has become a global environmental issue [49].

Based on the above considerations, the aim of this investigation is carried out to determine the adsorption potential of carbon nanoparticles for the removal REEs [Lanthanum (La III) and Neodymium (Nd III)] from a model solution of wastewater. The effective parameters such as solution $\mathrm{pH}$, dosage of CNMs, contact time factor and the initial concentration of REEs on the adsorption were optimized in order to achieve a better understanding of the adsorption process and to enhance the maximize efficiency of REEs removal from polluted water in batch experiments.

\section{Materials and Methods}

\subsection{Materials and Reagents}

Carbon nanoparticles were provided by D. Mendeleyev University of Chemical Technology of Russia and were used as received. Nanostructure of the CNPs was determined by Scanning electron microscope (scanning electron microscope EPMA JEOL 1610LV; SSD, X-Max, JEOL, Japan).

All glassware used in these experiments was acid-washed prior to use with nitric acid 5\%, $24 \mathrm{~h}$, and deionized (DI) water were used to prepare dilute solutions of the wastewater.

\subsection{Batch Adsorption Experiments}

Batch mode adsorption studies were carried out by soaking $25 \mathrm{mg}$ of the CNPs into $25 \mathrm{ml}$ wastewater containing Lanthanum(III) and Neodymium(III).

To study the effect of contact time, batch experimental procedures were conducted in different shaking times of: $25,50,75,100$, and $125 \mathrm{~min}$ at $\mathrm{pH}$ value of 3.0 , while the other parameters such as sorbent dosage $25 \mathrm{mg}$ and concentration of metals were kept constant.

Adsorption experiments were conducted by shaking $25 \mathrm{mg}$ of the CNPs with different initial concentrations of Lanthanum and Neodymium ranging from 1 to $30 \mu \mathrm{g} / \mathrm{l}$ for $2 \mathrm{~h}$. After separation, the final concentrations of metal ions in the solutions were measured.

To study the effect of sorbent dosage, batch experiments were conducted by mixing different sorbents masses of $0.01,0.02,0.03,0.04$ and $0.05 \mathrm{~g} / 25 \mathrm{ml}$ and the other parameters such as contact time $120 \mathrm{~min}, \mathrm{pH} 3$ and concentration of metals were kept constant.

Adsorption behaviors of $\mathrm{La}(\mathrm{III})$ and $\mathrm{Nd}(\mathrm{III})$ for the same initial concentration and equilibration time were studied as a function of $\mathrm{pH}$, the initial $\mathrm{pH}$ values were adjusted from 2.0 to 10.0 using solutions of $0.1 \mathrm{~mol} / \mathrm{L}$ of $\mathrm{H}_{2} \mathrm{SO}_{4}$ and $0.1 \mathrm{~mol} / \mathrm{L}$ of $\mathrm{NaOH}$ and the suspensions were obtained by adding $25 \mathrm{mg}$ of the adsorbent to $25 \mathrm{~mL}$ of metal solution. Then, the suspensions were agitated at desired speeds using a mechanical shaker for $120 \mathrm{~min}$ at $20^{\circ} \mathrm{C} \pm 1^{\circ} \mathrm{C}$ and monitoring the $\mathrm{pH}$ with calibrated $\mathrm{pH}$ meter. The removal efficiency of lanthanum and Neodymium was calculated as the difference between the initial and final concentrations when the equilibrium was reached. The results are based on at least three replicate experiments for each $\mathrm{pH}$ value.

After equilibrium was reached, the suspensions were filtered through $0.1 \mu \mathrm{m}$ membranes, and the initial and equilibrium metal concentrations then measured using the ICP-MS (XSeriesII Thermo Scientific Inc., USA). The removal efficiency of Lanthanum and Neodymium was calculated as the difference between initial and equilibrium metal concentration.

\subsection{Adsorption Kinetics}

The amount of metal ion adsorbed onto CNPs was expressed as the adsorption capacity and computed by the following equation [50]. 


$$
q_{t}=\frac{\left(C_{0}-C_{t}\right) V}{m_{s}}
$$

where:

$q$ is the amount of metals ions adsorbed by the carbon nanoparticles ( $\mathrm{mg} / \mathrm{g})$.

$C_{0}$ and $C_{t}$ are the initial and equilibrium concentrations of metal ions, respectively, in solution.

$V$ and $m$ are volume of solution and weight of adsorbent, respectively.

The percentage of removal efficiency $(E \%)$ of the adsorbent on metal ions in solution was calculated using the following relationship:

$$
E \%=\left(\frac{C_{o}-C_{e}}{C_{o}}\right) \times 100
$$

where: $C_{0}$ and $C_{e}$ are the initial and final concentration of heavy metals in the solution phase. All the batch experiments were performed in triplicate and the negative controls (with no adsorbent) were simultaneously carried out to determine metal ion loss during the adsorption due to the glassware or any of the experimental.

\section{Results and Discussion}

The physical characterization of the nanocomposite is crucial to prove that the nanomaterial was well developed. The textual structure of adsorbent surface (Figure 1) was observed by using a scanning electron microscope (Scanning electron microscope EPMA JEOL 1610LV; SSD, X-Max, JEOL, Japan).

The morphology of the investigated carbon nanoparticle samples is fairly heterogeneous and comprised of grains with particles sizes and the specific surface area was $>1800 \mathrm{~m}^{2} / \mathrm{g}$. The structural uniformity is lacking and grains of varying particle sizes reflects to the process used for synthesis of carbon nanoparticles.

Details of the microstructure of the particles and surface structure of CNPs are revealed by high-resolution TEM images, as shown in Figure 2. Clearly, the particles of these CNMs exhibit well-graphitized structure, and no amorphous carbon is present.
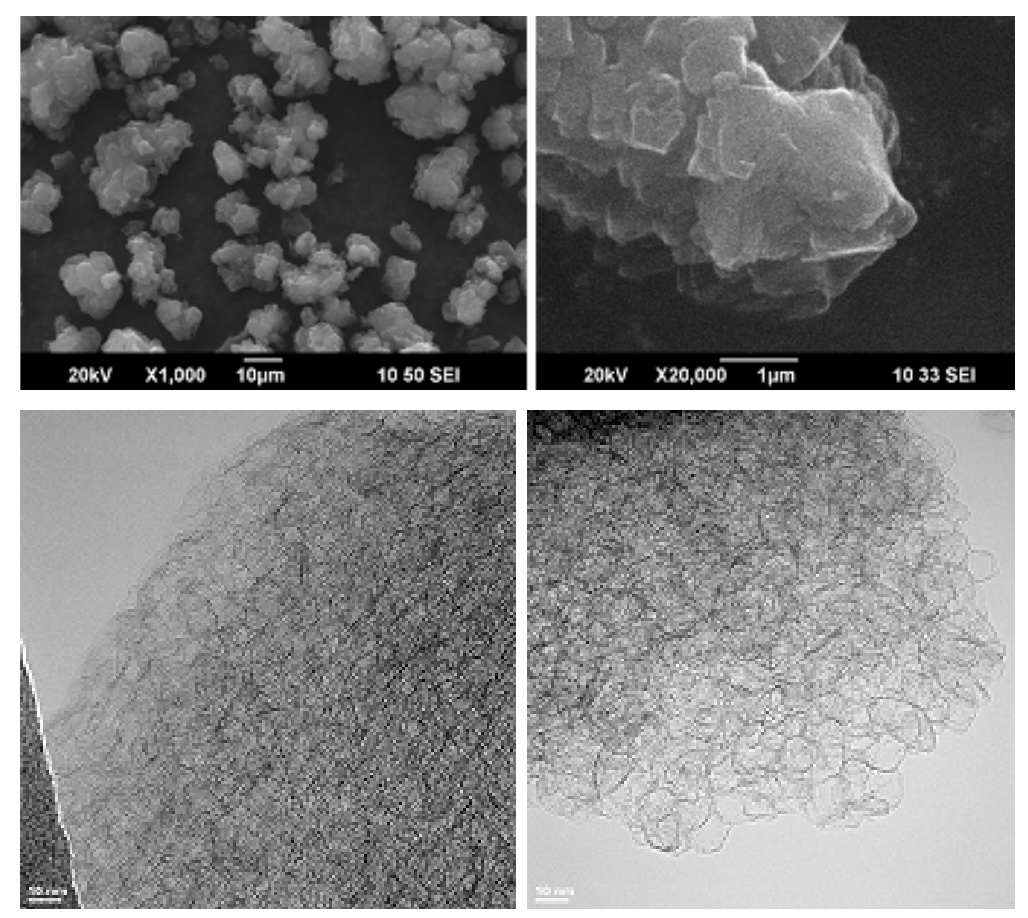

Figure 1. Scanning electron microscope images of carbon nanoparticles used for $\mathrm{La}(\mathrm{III})$ and $\mathrm{Nd}(\mathrm{III})$ adsorption from aqueous solution. 


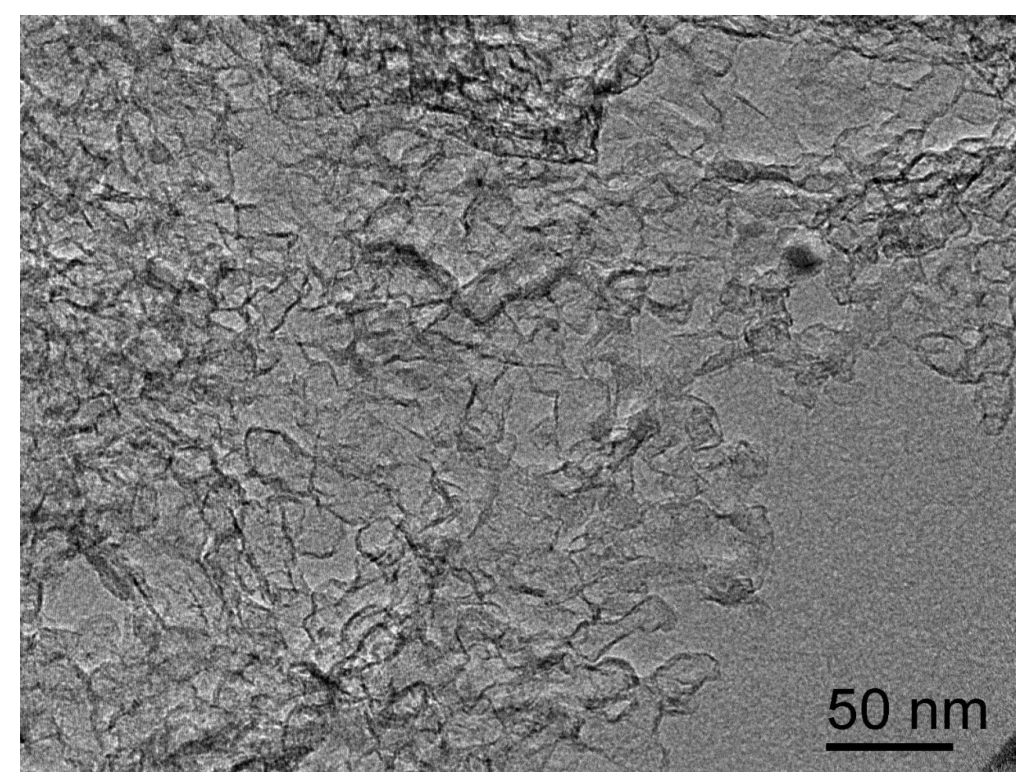

Figure 2. TEM image of carbon nanoparticles used for La(III) and Nd(III) adsorption from aqueous solution.

\subsection{Effect of Solution $\mathrm{pH}$}

Because the $\mathrm{pH}$ value of the solution acts as an important parameter controlling the adsorption process, which can alter the surface properties of the adsorbent by involving complex mechanisms [51], the influence of hydrogen ion concentration on the adsorption of $\mathrm{La}$ (III) and $\mathrm{Nd}(\mathrm{III})$ was conducted at $\mathrm{pH}$ levels ranging from 2.0 to 10.0. The relationship between the initial $\mathrm{pH}$ values and the quantities of $\mathrm{La}$ and $\mathrm{Nd}$ adsorbed on CNPs adsorbents is illustrated in Figure 3.

As shown in the figure, the adsorption of $\mathrm{La}(\mathrm{III})$ and $\mathrm{Nd}(\mathrm{III})$ on CNPs was strongly dependent on $\mathrm{pH}$. Clearly, the removal efficiency of La and Nd shows a gradual increased from $0.00 \%$ to $99.00 \%$ and $0.88 \%$ to $99.00 \%$ respectively. The percentage adsorption of $\mathrm{La}$ and $\mathrm{Nd}$ shows a gradual increase from $\mathrm{pH} 2$ to $\mathrm{pH} 7$, then the adsorption remains constant up to $\mathrm{pH} 10$.

The low sorption in the acidic region can be partially attributed to the positively charged sites in the acidic region is dominate; this enhances the electrostatic repulsion forces existing between the sorbent surface and metals [7]. Therefore, the active sites of adsorbents are less available to metal ions because of the protonation of active sites at the high concentration and mobility of the hydronium ions $(\mathrm{H}+)$ present favored the preferential adsorption of hydrogen ions over metal ions which lead to the high competitive adsorption between hydrogen ions and metals on the same sites. These changes could be explained by considering the surface charge of the carbon nanoparticles; the degree of ionisation; and the species of metals available in aqueous solution [52]. Hence, adsorbents have low capacity at low $\mathrm{pH}$ levels.

Higher $\mathrm{pH}$ is favorable for the deprotonation of hydroxyl groups on the sorbent surface [53]. Increased deprotonation results in the increase of the negatively charged sites, and then the linked $\mathrm{H}^{+}$released from the adsorbent is greater, consequently more active sites become available for binding with metal ions due to the decrease of protons $\left(\mathrm{H}^{+}\right)$in solution. Because of the release of $\mathrm{H}^{+}$from the surface, the surface charge of CNPs is more negatively charged, which enhances an electrostatic attraction forces between the sorbent surface and the metals; however, $\mathrm{La}(\mathrm{III})$ and $\mathrm{Nd}(\mathrm{III})$, which are positively charged, can easily bind to negatively dissociated forms of active groups and form metal complexes with surface groups, and thus results in an increase in the adsorption capacity [28] [54].

\subsection{Effect of Contact Time}

The time needed for the interaction between the adsorbate and adsorbent is crucial (i.e., the faster the removal, the better the adsorbent). Hence, it is important to study the effect of contact time on the removal of the target metals with carbon nanoparticles. 


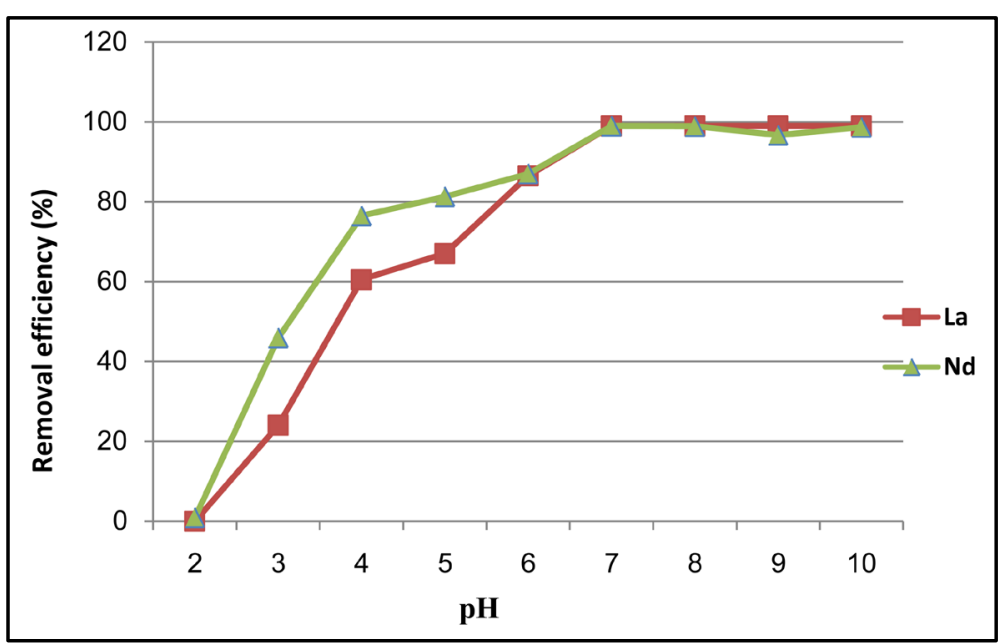

Figure 3. Effect of pH on the removal efficiency (\%) of La(III) and $\mathrm{Nd}(\mathrm{III})$ from aqueous solution by carbon nanoparticles (experimental conditions: $\mathrm{La}$ (III) and $\mathrm{Nd}(\mathrm{III})$ concentration $12 \mu \mathrm{g} / \mathrm{l}$, contact time $120 \mathrm{~min}$, adsorbent dosage 25 $\mathrm{mg} / 25 \mathrm{~mL}$ at room temperature).

Figure 4 shows the effect of contact time ranging from 20 to 120 min on the adsorption of $\mathrm{La}(\mathrm{III})$ and $\mathrm{Nd}(\mathrm{III})$ from an aqueous solution by CNPs as a function of contact time while all the other parameters were kept constant.

As can be observed, the \% adsorption of La and $\mathrm{Nd}$ were (8.48\% and $14.73 \%)$ after 20 min,and it increased gradually to reach $50.29 \%$ and $52.59 \%$, respectively, after 40 min of adsorption and then remained constant for the rest of the experimental time (120 min). Based on these results, the optimal removal of $\mathrm{La}(\mathrm{III})$ and $\mathrm{Nd}(\mathrm{III})$ from an aqueous solution by CNPs was practically achieved within $40 \mathrm{~min}$ for confident that equilibrium was achieved.

Figure 4 shows that the removal efficiency of La and Nd from the aqueous solution was increased quickly with time and then slowly reached equilibrium. The two steps adsorption, the first rapid and quantitatively predominant and the second slower and quantitatively insignificant, has been extensively reported in literature [55].

This observation demonstrates that the used nanostructured materials are more efficient because they can remove the metals much faster. Our results in agreement with previous studies, that have reported similar findings [56] [57].

\subsection{Effect of Carbon Nanoparticles Mass}

The aim of this section is determination the effect of sorbent dosage on removal efficiency that can be achieved at any $\mathrm{pH}$. The influence of the carbon nanoparticles dosage on the percentage of REEs adsorbed from aqueous solutions is shown in Figure 5. The experimental results revealed that the removal efficiencies of metalions increased with the increase in the sorbent mass.

An increase in the absorbent dosage from 0.01 to $0.02 \mathrm{~g} / 25 \mathrm{ml}$ led to an increase sharply in the percentage of removal efficiency of $\mathrm{La}(\mathrm{III})$ from 99.1 to 99.5 and from 99.1 to 99.4 for $\mathrm{Nd}(\mathrm{III})$ while with the increase in the amount of investigated CNPs from $0.03 \mathrm{~g}$ to $0.05 \mathrm{~g}$ further significantly improvements in the percentage sorption of metal ions were not observed.

The increase of sorption percentage of metals with a rise in mass of absorbent could be due to the fact that increasing the adsorbent dose provided a greater surface area and more in the availability of activated adsorption sites which lead to increasing number of binding sites for the metals [58] [59].

\subsection{Effect of Initial REEs Concentration}

REEs that are present in contaminated environments exist in different concentrations depending on the sources of contamination. Thus, the adsorption behavior of CNPs for removal performance of $\mathrm{La}$ (III) and $\mathrm{Nd}(\mathrm{III})$ from wastewater was investigated as a function of their concentrations at constant temperature $\left(25 \pm 0.1^{\circ} \mathrm{C}\right)$ by dif- 


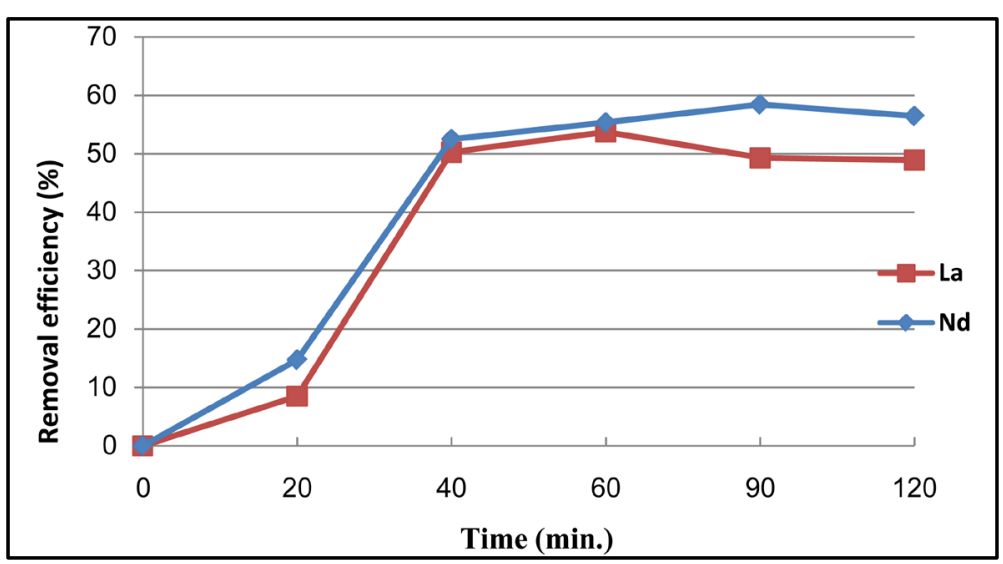

Figure 4. Effect of contact time on the removal efficiency of La(III) and Nd(III) from aqueous solution by carbon nanoparticles (experimental conditions: $\mathrm{La}$ (III) and $\mathrm{Nd}(\mathrm{III})$ concentration $12 \mu \mathrm{g} / \mathrm{l}, \mathrm{pH} 3.0$, adsorbent dosage $25 \mathrm{mg} / 25 \mathrm{~mL}$ at room temperature).

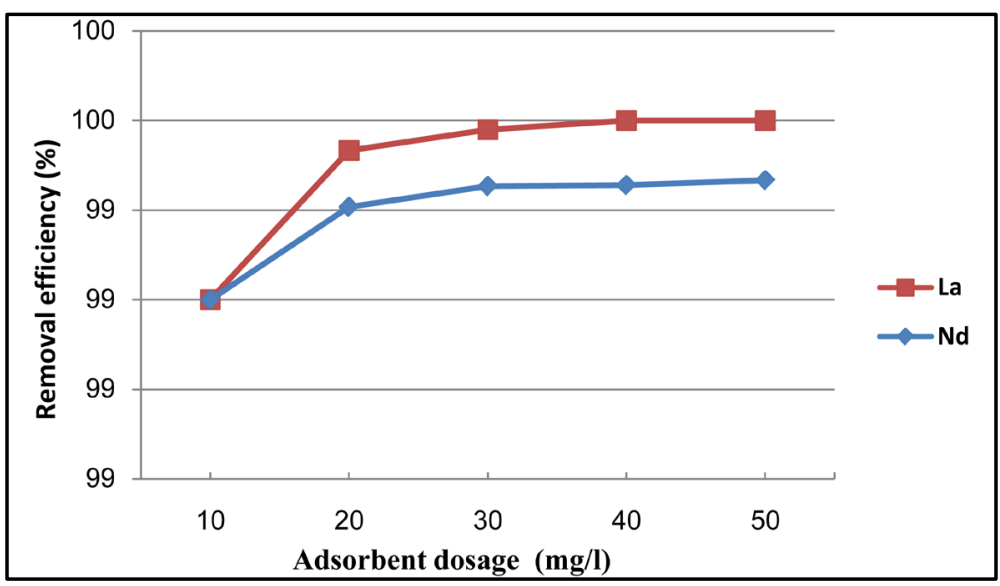

Figure 5. Effect of adsorbent dose on the removal efficiency of $\mathrm{La}(\mathrm{III})$ and $\mathrm{Nd}(\mathrm{III})$ from aqueous solution by carbon nanoparticles (experimental conditions: $\mathrm{La}(\mathrm{III})$ and $\mathrm{Nd}(\mathrm{III})$ concentration $12 \mu \mathrm{g} / \mathrm{l}, \mathrm{pH} 7.0$, contact time of 120 min at room temperature).

ferent initial metal concentration from 1 to $30 \mu \mathrm{g} \cdot \mathrm{L}^{-1}$, while keeping all other parameters constant. The sorption results of $\mathrm{La}(\mathrm{III})$ and $\mathrm{Nd}(\mathrm{III})$ using nanoparticles are shown in Figure 6.

Generally, for both elements the percentage of adsorption increases slightly with increasing amounts of metal concentrations adds. The \% adsorption of the $\mathrm{La}(\mathrm{III})$ and $\mathrm{Nd}(\mathrm{III})$ increased from 99.00 and 99.70 to 98.57 and 99.73\%, respectively, with increasing of metal ions concentration from $1.0 \mu \mathrm{g} / \mathrm{l}$ to $30.0 \mu \mathrm{g} / \mathrm{l}$. This observation could be attributed to saturation of the availability of active adsorption sites of the CNPs is still the same with increasing of metal ions concentration since the adsorbent used is the same [60].

This simply suggests that, the saturation of the available active sites could strongly depend on the $\mathrm{pH}$ of the solution and its dose rather than on the initial concentration [60].

\subsection{The Sorption Capacity}

The equilibrium sorption uptake (adsorption capacity) is one of the most important factor because it determines how much of the contaminant can be removed from the cleaned solution by a unit mass of the adsorbent.

Figure 7 shows the sorption capacity of REEs onto CNPs sorbent as the relationship between the amount of REEs sorbed per unit mass of a given CNPs based sorbent and the equilibrium concentration of the respective ion in solution with various $\mathrm{pH}$ values from 2.0 to 10.0. 


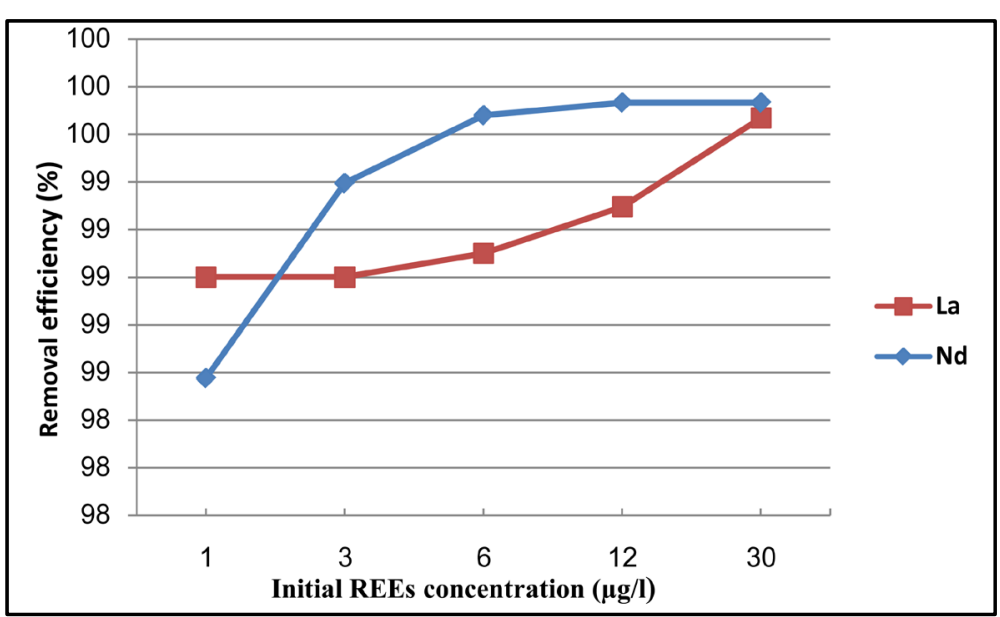

Figure 6. Effect of initial metal concentrations on adsorption of $\mathrm{La}(\mathrm{III})$ and $\mathrm{Nd}(\mathrm{III})$ onto carbon nanoparticles (experimental conditions: contact time 120 min, $\mathrm{pH} 7.0$, adsorbent dosage $25 \mathrm{mg} / 25 \mathrm{~mL}$ at room temperature).

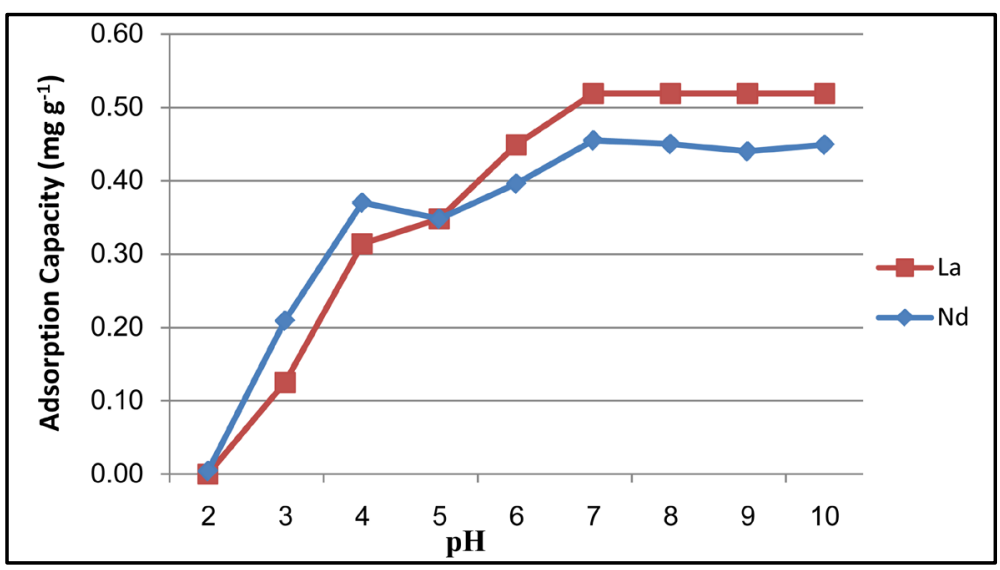

Figure 7. Adsorption capacity of $\mathrm{La}(\mathrm{III})$ and $\mathrm{Nd}(\mathrm{III})$ onto carbon nanoparticles Experimental conditions: $C_{0}=12 \mu \mathrm{g} / \mathrm{L}$; sorbent dose $25 \mathrm{mg} / 25 \mathrm{~mL}$, contact time $120 \mathrm{~min}$.

As observed in the figure, both the adsorption capacity of $\mathrm{La}(\mathrm{III})$ and $\mathrm{Nd}(\mathrm{III})$ present increasing trend with the rise of $\mathrm{pH}$ value. Moreover, it is observed that the adsorption capacity of $\mathrm{La}(\mathrm{III})$ is lower than that of $\mathrm{Nd}(\mathrm{III})$ in the $\mathrm{pH}$ ranging from 2.0 to 5.0 while the adsorption capacity of $\mathrm{La}(\mathrm{III})$ is higher than that of $\mathrm{Nd}(\mathrm{III})$ in the $\mathrm{pH}$ range from 6.0 to 10.0. This because of the lower penetration and inability of La to reach and occupy all active adsorption sites on CNPs sorbent in acidic region in comparison with $\mathrm{Nd}(\mathrm{III})$. While in alkaline region the investigated metals could be adsorbed on CNPs by the formation of metal complexes (covalent or ionic bonding) and/or precipitation and/or electrostatic attraction [28]. Preference of these mechanisms in each adsorbent and metal to some extent related to chemistry of metal, solution and nature of functional groups which induce negative charge on the CNPs surface and consequently oxygen atoms of these functional groups donate their single pair of electrons to the metal ions [26]. Therefore, the dominant mechanism adsorption of investigated REEs may be complexes and precipitation.

"This research was done at the expense of the grant of the Russian Science Foundation (project № 14-2900194) D.I. Mendeleev University of Chemical Technology of Russia."

\section{Conclusions}

The application of carbon nanoparticles for the removal of metal ions from wastewater is one of the pioneer studies which have been done in environmental field. 
In the present study, carbon nanoparticles was characterized with by field emission scanning electron microscopy and it has been investigated in the application as potential adsorbents to $\mathrm{La}(\mathrm{III})$ and $\mathrm{Nd}$ (III) from waste water. The efficiencies of the adsorbent have been determined by finding its adsorption capacity. The effects of varying parameters that affected the removal/adsorption process such as $\mathrm{pH}$ of the solution, the adsorbent dose, the time contact and the initial concentration of REEs were investigated.

The results demonstrated that CNPs could remove both of $\mathrm{La}(\mathrm{III})$ and $\mathrm{Nd}(\mathrm{III})$ from wastewater successfully and the percentage adsorption of La and Nd on CNPs was strongly dependent on $\mathrm{pH}$. The removal efficiency of $\mathrm{La}$ (III) and $\mathrm{Nd}(\mathrm{III})$ shows a gradual increase from $\mathrm{pH} 2$ to $\mathrm{pH}$ 7, and then the adsorption remains constant up to $\mathrm{pH}$ 10. Similar trend has been found in the effect of contact time which increases remarkably at the beginning of the experiment and then reaches equilibrium at $40 \mathrm{~min}$.

The optimum absorbent dosage to achieve the maximum adsorption capacity was $0.02 / 25 \mathrm{ml}$ and the percentage of adsorption increases for both elements slightly with decreasing amounts of metal concentrations adds.

\section{References}

[1] (2007) Agency for Toxic Substances and Disease Registry, ATSDR, CERCLA Priority List of Hazardous Substances.

[2] Aklil, A., Mouflih, M. and Sebti, S. (2004) Removal of Heavy Metal Ions from Water by Using Calcined Phosphate as a New Adsorbent. Journal of Hazardous Materials, A112, 183-190. http://dx.doi.org/10.1016/j.jhazmat.2004.05.018

[3] Wang, J.H., Zheng, S.R., Shao, Y., Liu, J.L., Xu, Z.Y. and Zhu, D.Q. (2010) Amino-Functionalized $\mathrm{Fe}_{3} \mathrm{O}_{4} @ \mathrm{SiO}_{2}$ Core-Shell Magnetic Nanomaterial as a Novel Adsorbent for Aqueous Heavy Metals Removal. Journal of Colloid and Interface Science, 349, 293-299. http://dx.doi.org/10.1016/j.jcis.2010.05.010

[4] Viard, B., Pihan, F., Promeyrat, S and Pihan, J.C. (2004) Integrated Assessment of Heavy Metal (Pb, Zn, Cd) Highway Pollution: Bioaccumulation in Soil, Graminaceae and Land Snails. Chemosphere, 55, 1349-1359. http://dx.doi.org/10.1016/i.chemosphere.2004.01.003

[5] Abdel Salam, M., Al-Zhrani, G. and Kosa, S.A. (2012) Simultaneous Removal of Copper(II), Lead(II), Zinc(II) and Cadmium(II) from Aqueous Solutions by Multi-Walled Carbon Nanotubes. Comptes Rendus Chimie, 15, 398-408. http://dx.doi.org/10.1016/j.crci.2012.01.013

[6] Younis, A.M., El-Zokm G.M. and Okbah, M.A. (2014) Spatial Variation of Acid-Volatile Sulfide and Simultaneously Extracted Metals in Egyptian Mediterranean Sea Lagoon Sediments. Environmental Monitoring \& Assessment, 186, 3567-3579. http://dx.doi.org/10.1007/s10661-014-3639-3

[7] Roy, A. and Bhattacharya, J. (2012) Removal of Cu(II), Zn(II) and Pb(II) from Water Using Microwave-Assisted Synthesized Maghemite Nanotubes. Chemical Engineering Journal, 211-212, 493-500. http://dx.doi.org/10.1016/j.cej.2012.09.097

[8] Ali Atieh, M. (2011) Removal of Chromium (VI) from Polluted Water Using Carbon Nanotubes Supported with Activated Carbon. Procedia Environmental Sciences, 4, 281-293. http://dx.doi.org/10.1016/j.proenv.2011.03.033

[9] Saito, T., Tsuneda, S., Hirata, A., Nishiyama, S., Saito, K., Saito, K., Sugita, K., Uezu, K., Tamada, M. and Sugo, T. (2004) Removal of Antimony (III) Using Polyol-Ligand-Containing Porous Hollow-Fiber Membranes. Separation Science and Technology, 39, 3011-3022. http://dx.doi.org/10.1081/SS-200033727

[10] Zouboulis, A.I., Matis, K.A., Lanara, B.G. and Loos-Neskovic, C. (1997) Removal of Cadmium from Dilute Solutions by Hydroxyapatite. II. Flotation Studies. Separation Science and Technology, 32, 1755-1767. http://dx.doi.org/10.1080/01496399708000733

[11] Mok, W.M. and Wai, C.M. (1990) Distribution and Mobilization of Arsenic and Antimony Species in the Coeur D’Alene River, Idaho. Environmental Science \& Technology, 24, 102-108. http://dx.doi.org/10.1021/es00071a012

[12] Elouear, Z., Bouzid, J., Boujelben, N., Feki, M., Jamoussi, F. and Montiel, A. (2008) Heavy Metal Ions Removal from Aqueous Solutions by Activated Phosphate Rock. Journal of Hazardous Materials, 156, 412-420. http://dx.doi.org/10.1016/j.jhazmat.2007.12.036

[13] Bhattacharyya, K.G. and Sen Gupta, S. (2008) Influence of Acid Activation on Adsorption of Ni(II) and Cu(II) on Kaolinite and Montmorillonite: Kinetic and Thermodynamic Study. Chemical Engineering Journal, 136, 1-13. http://dx.doi.org/10.1016/j.cej.2007.03.005

[14] Chang, P., Yu, S., Chen, T., Ren, A., Chen, C. and Wang, X. (2007) Effect of pH, Ionic Strength, Fulvic Acid and Humic Acid on Sorption of Th(IV) on Na-Rectorite. Journal of Radioanalytical and Nuclear Chemistry, 274, 153-160. http://dx.doi.org/10.1007/s10967-006-6865-5

[15] Demirbas, E., Dizge, N., Sulak, M.T. and Kobya, M. (2009) Adsorption Kinetics and Equilibrium of Copper from Aqueous Solutions Using Hazelnut Shell Activated Carbon. Chemical Engineering Journal, 148, 480-487. 
http://dx.doi.org/10.1016/j.cej.2008.09.027

[16] Sheng, G.D., Shao, D.D., Fan, Q.H., Xu, D., Chen, Y.X. and Wang, X.K. (2009) Effect of pH and Ionic Strength on Sorption of Eu(III) to MX-80 Bentonite: Batch and XAFS Study. Radiochimica Acta, 97, 621-630. http://dx.doi.org/10.1524/ract.2009.1656

[17] Srivastava, V.C., Mall, I.D. and Mishra, I.M. (2007) Adsorption Thermodynamics and Isosteric Heat of Adsorption of Toxic Metal Ions onto Bagasse Fly Ash (BFA) and Rice Husk Ash (RHA). Chemical Engineering Journal, 132, 267278. http://dx.doi.org/10.1016/j.cej.2007.01.007

[18] Ayala, J., Blanco, F., Garcia, P., Rodriguez, P. and Sancho, J. (1998) Asturian Fly Ash as a Heavy Metals Removal Material. Fuel, 77, 1147-1154. http://dx.doi.org/10.1016/S0016-2361(98)00027-1

[19] Weng, C.H. and Huang, C.P. (2004) Adsorption Characteristics of Zn(II) from Dilute Aqueous Solution by Fly Ash. Colloids and Surfaces A, 247, 137-143.

[20] Rao, M.M., Ramesh, A., Rao, G.P.C. and Seshaiah, K. (2006) Removal of Copper and Cadmium from the Aqueous Solutions by Activated Carbon Derived from Ceiba pentandra Hulls. Journal of Hazardous Materials, 129, 123-129. http://dx.doi.org/10.1016/j.jhazmat.2005.08.018

[21] Secar, M., Sakthi, V. and Rengaraj, S. (2004) Kinetics Equilibrium Adsorption Study of Lead(II) onto Activated Carbon from Coconut Sell. Journal of Colloid and Interface Science, 279, 307-313. http://dx.doi.org/10.1016/j.jcis.2004.06.042

[22] Sublet, R., Simonnot, M.O., Boireau, A. and Sardin, M. (2003) Selection of an Adsorbent for Lead Removal from Drinking Water by a Point-of-Use Treatment Device. Water Research, 37, 4904-4912. http://dx.doi.org/10.1016/j.watres.2003.08.010

[23] Biskup, B. and Subotic, B. (2004) Removal of Heavy Metal Ions from Solutions Using Zeolites. III. Influence of Sodium Ion Concentration in the Liquid Phase on the Kinetics of Exchange Processes between Cadmium Ions from Solution and Sodium Ions from Zeolite A. Separation Science and Technology, 39, 925-940. http://dx.doi.org/10.1081/SS-120028454

[24] Li, Q., Wu, S., Liu, G., Liao, X., Deng, X., Sun, D., Hu, Y.L. and Huang, Y.L. (2004) Simultaneous Biosorption of Cadmium (II) and Lead (II) Ions by Pretreated Biomass of Phanerochaete chrysosporium. Separation and Purification Technology, 34, 135-142. http://dx.doi.org/10.1016/S1383-5866(03)00187-4

[25] Ekmekyapar, F., Aslan, A., Bayhan, Y.K. and Cakici, A. (2006) Biosorption of Copper(II) by Nonliving Lichen Biomass of Cladonia rangiformis Hoffm. Journal of Hazardous Materials, 137, 293-298. http://dx.doi.org/10.1016/j.jhazmat.2006.02.003

[26] Rao, G.P., Lu, C. and Su, F.S. (2007) Sorption of Divalent Metal Ions from Aqueous Solution by Carbon Nanotubes: A Review. Separation and Purification Technology, 58, 224-231. http://dx.doi.org/10.1016/j.seppur.2006.12.006

[27] Rupareliaa, J.P., Duttaguptab, S.P., Chatterjeec, A.K. and Mukherjia, S. (2008) Potential of Carbon Nanomaterials for Removal of Heavy Metals from Water. Desalination, 232, 145-156. http://dx.doi.org/10.1016/j.desal.2007.08.023

[28] Afkhami, A. and Moosavi, R. (2010) Adsorptive Removal of Congo Red, a Carcinogenic Textile Dye, from Aqueous Solutions by Maghemite Nanoparticles. Journal of Hazardous Materials, 174, 398-403. http://dx.doi.org/10.1016/j.jhazmat.2009.09.066

[29] Rahmani, A., Zavvar Mosavi, H. and Fazli, M. (2010) Effect of Nanostructure Alumina on Adsorption of Heavy Metals. Desalination, 253, 94-100. http://dx.doi.org/10.1016/j.desal.2009.11.027

[30] Wang, P., Shi, Q.H., Liang, H.J., Steuerman, D.W., Stucky, G.D. and Keller, A.A. (2008) Enhanced Environmental Mobility of Carbon Nanotubes in the Presence of Humic Acid and Their Removal from Aqueous Solution. Small, 4, 2166-2170. http://dx.doi.org/10.1002/smll.200800753

[31] Lu, C., Chiu, H. and Liu, C.T. (2006) Removal of Zinc(II) from Aqueous Solution by Purified Carbon Nanotubes: Kinetics and Equilibrium Studies. Industrial \& Engineering Chemistry Research, 45, 2850-2855. http://dx.doi.org/10.1021/ie051206h

[32] Chen, C., Hu, J., Shao, D., Li, J. and Wang, X.K. (2009) Adsorption Behavior of Multiwall Carbon Nanotube/Iron Oxide Magnetic Composites for Ni(II) and Sr(II). Journal of Hazardous Materials, 164, 923-928. http://dx.doi.org/10.1016/j.jhazmat.2008.08.089

[33] Peng, X., Luan, Z., Di, Z., Zhang, Z. and Zhu, C. (2005) Carbon Nanotubes-Iron Oxides Magnetic Composites as Adsorbent for Removal of $\mathrm{Pb}(\mathrm{II})$ and $\mathrm{Cu}(\mathrm{II})$ from Water. Carbon, 43, 880-883. http://dx.doi.org/10.1016/j.carbon.2004.11.009

[34] Gong, J.L., Wang, B., Zeng, G.M., Yang, C.P., Niu, C.G., Niu, Q.Y., Zhou, W.J. and Liang, Y. (2009) Removal of Cationic Dyes from Aqueous Solution Using Magnetic Multi-Wall Carbon Nanotube Nanocomposite as Adsorbent. Journal of Hazardous Materials, 164, 1517-1522. http://dx.doi.org/10.1016/j.jhazmat.2008.09.072 
[35] Zhou, Q., Xiao, J. and Wang, W. (2006) Using Multi-Walled Carbon Nanotubes as Solid Phase Extraction Adsorbents to Determine Dichlorodiphenyltrichloroethane and Its Metabolites at Trace Level in Water Samples by High Performance Liquid Chromatography with UV Detection. Journal of Chromatography A, 1125, 152-158. http://dx.doi.org/10.1016/j.chroma.2006.05.047

[36] Basheer, C., Alnedhary, A.A., Rao, B.S.M., Valiyaveettil, S. and Lee, H.K. (2006) Development and Application of Porous Membrane-Protected Carbon Nanotube Micro-Solid-Phase Extraction (m-SPE) Combined with Gas Chromatography/Mass Spectrometry. Analytical Chemistry, 78, 2853-2858. http://dx.doi.org/10.1021/ac060240i

[37] Abdel Salam, M., Mokhtar, M., Basahel, S.N., Al-Thabaiti, S.A. and Obaid, A.Y. (2010) Removal of Chlorophenol from Aqueous Solutions by Multi-Walled Carbon Nanotubes: Kinetic and Thermodynamic Studies. Journal of Alloys and Compounds, 500, 87-92. http://dx.doi.org/10.1016/j.jallcom.2010.03.217

[38] Abdel Salam, M. and Burk, R. (2010) Thermodynamics and Kinetics Studies of Pentachlorophenol Adsorption from Aqueous Solutions by Multi-Walled Carbon Nanotubes. Water, Air, \& Soil Pollution, 210, 101-111. http://dx.doi.org/10.1007/s11270-009-0227-1

[39] Kueseng, P., Thammakhet, C., Thavarungkul, P. and Kanatharana, P. (2010) Multiwalled Carbon Nanotubes/Cryogel Composite, a New Sorbent for Determination of Trace Polycyclic Aromatic Hydrocarbons. Microchemical Journal, 96, 317-323. http://dx.doi.org/10.1016/j.microc.2010.05.002

[40] Dia, A., Gruau, G., Olivié-Lauquet, G., Riou, C., Molénat, J. and Curmi, P. (2000) The Distribution of Rare Earth Elements in Groundwaters: Assessing the Role of Source-Rock Composition, Redox Changes, and Colloidal Particles. Geochimica et Cosmochimica Acta, 64, 4131-4151. http://dx.doi.org/10.1016/S0016-7037(00)00494-4

[41] Gai, S.L., Yang, G.X., Li, X.B., Li, C.X., Dai, Y.L., He, F. and Yang, P.P. (2012) Facile Synthesis and Up-Conversion Properties of Monodisperse Rare Earth Fluoride Nanocrystals. Dalton Transactions, 41, 11716-11724. http://dx.doi.org/10.1039/c2dt30954h

[42] Hinton, B.R.W., Behrouzvaziri, M., Forsyth, M., Gupta, R.K., Seter, M. and Bushell, P.G. (2012) The Inhibition of Hydrogen Embrittlement in SAE 4340 Steel in an Aqueous Environment with the Rare Earth Compound Lanthanum 4 Hydroxy Cinnamate. Metallurgical and Materials Transactions A, 43, 2251-2259. http://dx.doi.org/10.1007/s11661-012-1103-y

[43] Minowa, T. (2008) Rare Earth Magnets: Conservation of Energy and the Environment. Resource Geology, 58, 414422.

[44] Hu, Z., Richter, H., Sparovek, G. and Schnug, E. (2004) Physiological and Biochemical Effects of Rare Earth Elements on Plants and Their Agricultural Significance: A Review. Journal of Plant Nutrition, 27, 183-220. http://dx.doi.org/10.1081/PLN-120027555

[45] Pang, X., Li, D. and Peng, A. (2002) Application of Rare-Earth Elements in the Agriculture of China and Its Environmental Behavior in Soil. Environmental Science and Pollution Research, 9, 143-148. http://dx.doi.org/10.1007/BF02987462

[46] Suzuki, Y., Hikida, S. and Furuta, N. (2011) Cycling of Rare Earth Elements in the Atmosphere in Central Tokyo. Journal of Environmental Monitoring, 13, 3420-3428.

[47] Hu, Z., Haneklaus, S., Sparovek, G. and Schnug, E. (2006) Rare Earth Elements in Soils. Communications in Soil Science and Plant Analysis, 37, 1381-1420.

[48] Gu, Z., Wang, X., Gu, X., Cheng, J., Wang, L., Dai, L. and Chen, Y.J. (2001) Effects of Fulvic Acid on the Bioavailability of Rare Earth Elements and GOT Enzyme Activity in Wheat (Triticum aestivum). Chemosphere, 44, 545-551. http://dx.doi.org/10.1016/S0045-6535(00)00484-7

[49] Zhen, C., Ma, W. and Han, M. (2008) Biosorption of Nickel and Copper onto Treated Alga (Undaria pinnatifida): Application of Isotherm and Kinetic Models. Journal of Hazardous Materials, 155, 327-333. http://dx.doi.org/10.1016/j.jhazmat.2007.11.064

[50] Venkata Ramana, D.K., Kumar Reddy, D.H.K., Jae Su, Y. and Seshaiah, K. (2012) Pigeon Peas Hulls Waste as Potential Adsorbent for Removal of $\mathrm{Pb}(\mathrm{II})$ and $\mathrm{Ni}(\mathrm{II})$ from Water. Chemical Engineering Journal, 197, 24-33. http://dx.doi.org/10.1016/j.cej.2012.04.105

[51] Tan, X.L., Fang, M., Chen, C.L., Yu, S.M. and Wang, X.K. (2008) Counterion Effects of Nickel and Sodium Dodecylbenzene Sulfonate Adsorption to Multiwalled Carbon Nanotubes in Aqueous Solution. Carbon, 46, 1741-1750. http://dx.doi.org/10.1016/j.carbon.2008.07.023

[52] Johnson, S.B., Franks, G.V., Scales, P.J., Boger, D.V. and Healy, T.W. (2000) Surface Chemistry-Rheology Relationships in Concentrated Mineral Suspensions. International Journal of Mineral Processing, 58, 267-304. http://dx.doi.org/10.1016/S0301-7516(99)00041-1

[53] Luo, F., Liu, Y., Li, X., Xuan, Z. and Ma, J. (2006) Biosorption of Lead Ion by Chemically-Modified Biomass of Marine Brown Algae Laminaria japonica. Chemosphere, 64, 1122-1127. 
http://dx.doi.org/10.1016/j.chemosphere.2005.11.076

[54] Sari, A., Tuzen, M., Citak, D. and Soylak, M. (2007) Adsorption Characteristics of Cu(II) and Pb(II) onto Expanded Perlite from Aqueous Solution. Journal of Hazardous Materials, 148, 387-394. http://dx.doi.org/10.1016/j.jhazmat.2007.02.052

[55] Uluozlu, O.D., Sari, A. and Tuzen, M. (2010) Biosorption of Antimony from Aqueous Solution by Lichen (Physcia tribacia) Biomass. Chemical Engineering Journal, 163, 382-388. http://dx.doi.org/10.1016/j.cej.2010.08.022

[56] Xi, J., He, M. and Lin, C. (2011) Adsorption of Antimony(III) and Antimony(V) on Bentonite: Kinetics, Thermodynamics and Anion Competition. Microchemical Journal, 97, 85-91. http://dx.doi.org/10.1016/j.microc.2010.05.017

[57] Lazaridis, N.K. and Charalambous, C. (2005) Sorptive Removal of Trivalent and Hexavalent Chromium from Binary Aqueous Solutions by Composite Alginate-Goethite Beads. Water Research, 39, 4385-4396. http://dx.doi.org/10.1016/j.watres.2005.09.013

[58] Chen, J.P. and Yang, L. (2006) Study of a Previous Term Heavy Metal Next Term Biosorption onto Raw and Chemically Modified Sargassum sp. via Spectroscopic and Modeling Analysis. Langmuir, 22, 8906-8914. http://dx.doi.org/10.1021/la060770+

[59] Muleja Anga, A., YangkouMbianda, X., Pillay, K. and Krause, R. (2012) Phosphine Functionalised Multiwalled Carbon Nanotubes: A New Adsorbent for the Removal of Nickel from Aqueous Solution. Journal of Environmental Sciences, 24, 1133-1141. http://dx.doi.org/10.1016/S1001-0742(11)60880-2

[60] Li, Y.H., Wang, S., Wei, J., Zhang, X., Xu, C., Luan, Z., Wu, D. and Wei, B. (2002) Lead Adsorption on Carbon Nanotubes. Chemical Physics Letters, 357, 263-266. http://dx.doi.org/10.1016/S0009-2614(02)00502-X 
Scientific Research Publishing (SCIRP) is one of the largest Open Access journal publishers. It is currently publishing more than 200 open access, online, peer-reviewed journals covering a wide range of academic disciplines. SCIRP serves the worldwide academic communities and contributes to the progress and application of science with its publication.

Other selected journals from SCIRP are listed as below. Submit your manuscript to us via either submit@scirp.org or Online Submission Portal.
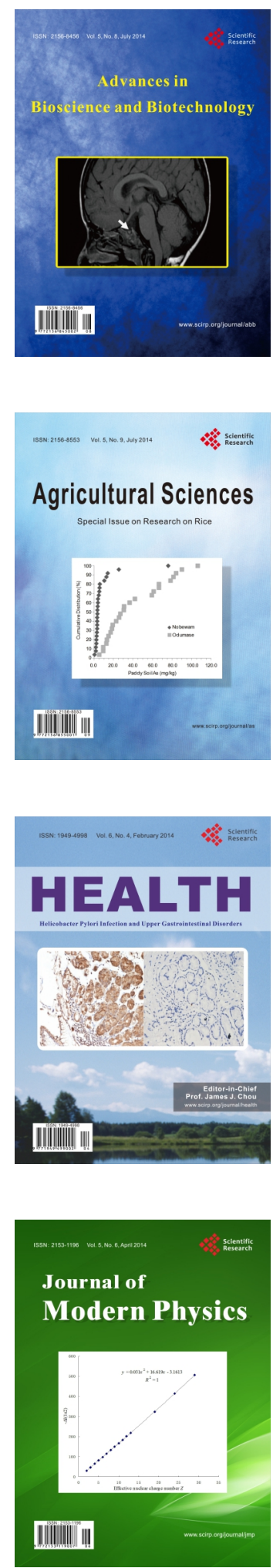
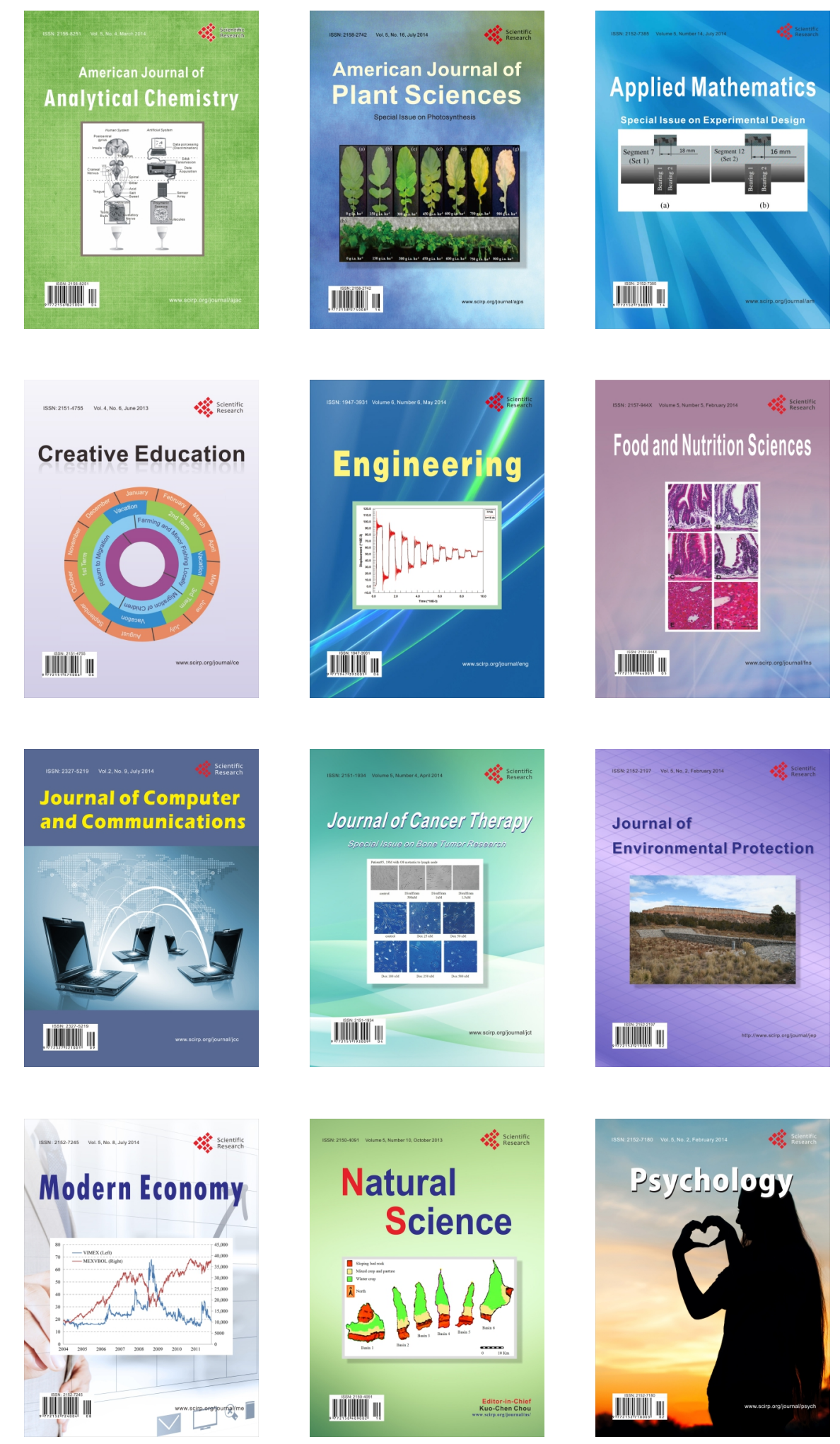